\title{
AN ELECTRIC RAY AND ITS YOUNG FROM THE WEST COAST OF FLORIDA.
}

\author{
By Barton A. Bean and Alfred C. Weed, \\ Of the Division of Fishes, U. S. National Museum.
}

Under date of July 21, 1910, Mr. A. G. Reynolds, of Veteran, Hillsboro County, Florida, addressed the U. S. National Museum as follows:

A few days ago an electric ray or torpedo (Torpedo) fish (Tetronarce occidentalis Storer) 17 by 9 inches in size, gave birth in my laboratory, to fourteen young ones, nine males and five females, about $3 \frac{1}{2}$ by 2 inches in size. Is this fact of any special interest, or would the specimens themselves be an acquisition to the Museum?

In answer to a memorandum sent Mr. Reynolds by the Museum, the following letter, dated August 13, 1910, was received from him:

Yesterday I sent you by express the torpedo and fourteen young ones mentioned in a previous letter. The specimens are cured in formaldehyde. I fear I did not make it very clear about the young ones. The mother was dead when received, the birth of the family being forced. She was caught in a net off Long Key (opposite here) by a pompano fisherman.

I think by your letter you were expecting these fish to be alive, but trust the preserved specimens will be of use to you.

The ray and fourteen young in a fine state of preservation were duly received and proved to be Narcine brasitiensis. Excellent photographs were taken by Mr. T. W. Smillie, the photographer of the U. S. National Museum. The following comparisons between the adult and young, as well as with the variety umbrosa, are given as a slight addition to our present knowledge of this interesting species:

The size of the specimens is sufficiently indicated in the letter quoted.

A few facts concerning the coloration, and other characters of these and the other specimens in the U. S. National Museum should be noted.

1. The dark patch across the snout seems to be a constant character which appears more or less prominently at all ages and in all the color varieties. 
2. The shape of the caudal fin is variable, the young (fetal) specimens having the caudal rounded (see plate 11) while in the adults it is truncate. (See plate 10.)

3. The adult males seem to be proportionally narrower than the females. This difference is not apparent in the young. The males that are referable to the subspecies umbrosa are especially narrow. We have no females of this form.

4. The difference in color between the young and the adult should be noted. The young have the dark spots very definite in outline while in the adult they are much less distinct and are sometimes formed by a close grouping of small spots about the size of a pin head. An interesting life-history note on Narcine brasiliensis by Russell J. Coles is published in Bulletin 28, of the American Museum of Natural History, 1910, page 337. We quote the note in full:

In July, 1909, I first saw this electric ray and captured two specimens which were presented to the laboratory of the Bureau of Fisheries at Beaufort, N. C. They were the first recorded on our Atlantic coast north of Florida. In July, 1910, I captured and preserved eleven specimens at Cape Lookout and know of the capture of more than a dozen others by the native fishermen during the same week; and none were seen either before or after that week. This ray can give a very powerful electric shock. I have been knocked down many times by this shock while experimenting with the fish, yet could make no record of this peculiar form of electricity as it had no effect on my battery-testing ammeter and it would not light a little electric lamp which only required two and a half volts. Probably it might have been recorded by a voltmeter, but I had none with me.

Several specimens which I found buried in the sand in shallow water with only the eyes and a little of the head and back showing were speared, and others were caught in the haul net.

Several bare foot native fishermen were knocked down by accidentally stepping on them in shallow water. These rays remain soft and rubber like in a formalin solution which hardens other specimens. 

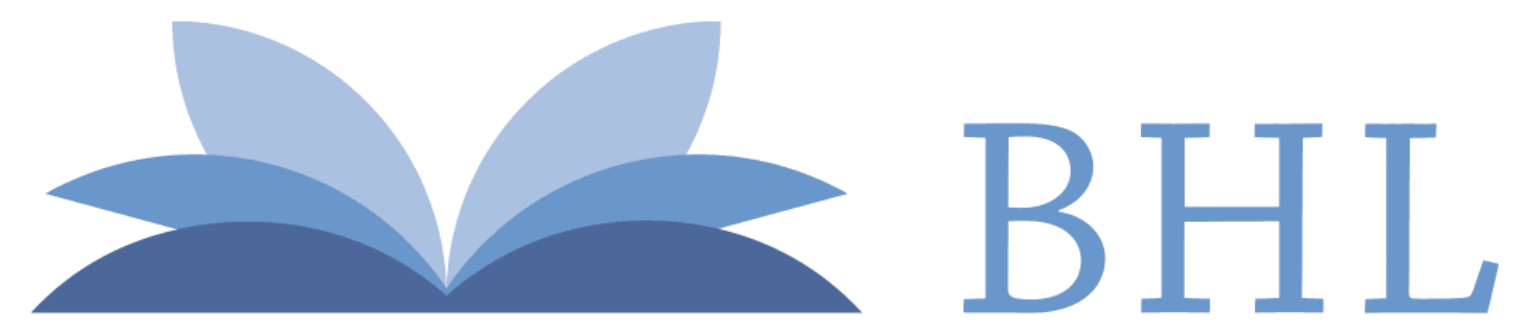

\section{Biodiversity Heritage Library}

Bean, Barton A. and Weed, Alfred C. 1911. "An electric ray and its young from the west coast of Florida." Proceedings of the United States National Museum 40(1816), 231-232. https://doi.org/10.5479/si.00963801.40-1816.231.

View This Item Online: $\underline{\text { https://www.biodiversitylibrary.org/item/53820 }}$

DOI: https://doi.org/10.5479/si.00963801.40-1816.231

Permalink: https://www.biodiversitylibrary.org/partpdf/53273

\section{Holding Institution}

Smithsonian Libraries

\section{Sponsored by}

Smithsonian

\section{Copyright \& Reuse}

Copyright Status: Public domain. The BHL considers that this work is no longer under copyright protection.

This document was created from content at the Biodiversity Heritage Library, the world's largest open access digital library for biodiversity literature and archives. Visit BHL at https://www.biodiversitylibrary.org. 